\title{
Methods of soil sterilization contaminated with spores of Plasmodiophora brassicae, causal agent of clubroot
}

\author{
Metody sterylizacji gleby zanieczyszczonej \\ zarodnikami Plasmodiophora brassicae, sprawcy kiły kapusty
}

\author{
Agnieszka Perek*, Ewa Jajor, Katarzyna Pieczul, Ilona Świerczyńska, Marek Korbas
}

\begin{abstract}
Summary
Plasmodiophora brassicae, the protozoan pathogen that causes clubroot on cabbage plants, is now a significant problem in oilseed rape crops. Due to numerous scientific studies in which the soil containing the spores of this pathogen is used, thorough sterilization of the infected medium has become very important. The aim of the study was to determine the possibility of effective sterilization of the soil and to define the factors affecting the viability of pathogen spores. The soil contaminated with $P$. brassicae spores, was subjected to the following processes: combustion, autoclaving, sterilization in the Koch apparatus, exposure to increased temperature, freezing at $-80^{\circ} \mathrm{C}$, disinfection with sodium hypochlorite and fungicides. The study showed that combustion, autoclaving and high temperature operation were the most effective ways to destroy spores in soil. Heating the soil showed that temperatures already above $70^{\circ} \mathrm{C}$ affected spore viability, while deep freezing of infected soil was completely ineffective. The use of Altima 500 SC significantly reduced plant infection.
\end{abstract}

Key words: Plasmodiophora brassicae, soil sterilization, resting spores

\section{Streszczenie}

Plasmodiophora brassicae, pierwotniak powodujący kiłę kapusty na roślinach z rodziny kapustowatych, stanowi obecnie poważny problem w uprawach rzepaku. W związku z licznymi badaniami naukowymi, w których wykorzystuje się glebę zawierającą zarodniki tego patogena bardzo istotna stała się dokładna sterylizacja zainfekowanego podłoża. Celem pracy było określenie możliwości skutecznej sterylizacji gleby oraz wyznaczenie czynników wpływających na żywotność zarodników patogena. W doświadczeniu wykorzystano glebę zanieczyszczoną zarodnikami $P$. brassicae, którą poddano procesom: spalania, sterylizacji w autoklawie, sterylizacji w aparacie Kocha, działaniu podwyższonej temperatury, mrożenia w temperaturze $-80^{\circ} \mathrm{C}$, dezynfekcji podchlorynem sodu oraz fungicydami. Doświadczenie wykazało, że najskuteczniejszą metodą niszczenia zarodników jest spalanie gleby, autoklawowanie oraz działanie wysokiej temperatury. Podgrzewanie gleby wykazało, że już temperatury powyżej $70^{\circ} \mathrm{C}$ wpływały na żywotność zarodników, natomiast głębokie mrożenie zainfekowanej gleby było zupełnie nieskuteczne. Zastosowanie fungicydu Altima 500 SC w znacznym stopniu ograniczyło infekcję roślin.

Słowa kluczowe: Plasmodiophora brassicae, sterylizacja gleby, zarodniki przetrwalnikowe

\author{
Instytut Ochrony Roślin - Państwowy Instytut Badawczy \\ Zakład Mikologii \\ Władysława Węgorka 20, 60-318 Poznań \\ *corresponding author: a.perek@iorpib.poznan.pl
}




\section{Wstęp / Introduction}

Kiła kapusty powodowana przez pierwotniaka Plasmodiophora brassicae należy do najpoważniejszych chorób rzepaku oraz innych roślin z rodziny kapustowatych (Korbas i wsp. 2009; Korbas i Jajor 2013). Dane wskazują, że obecnie około 250 tys. ha gleb w Polsce przeznaczanych pod uprawę rzepaku, jest zanieczyszczonych zarodnikami tego patogena (Konieczny 2012). Utrudnieniem w walce z kiłą kapusty są tworzone przez $P$. brassicae zarodniki przetrwalnikowe. Charakteryzują się one dużą odpornością zarówno na oddziaływanie niekorzystnych warunków środowiska, jak również środków chemicznych, dzięki czemu mogą zachować żywotność w glebie, nawet powyżej 20 lat (Wallenhammar 1996; Rimmer i wsp. 2007). Liczne badania wskazują, że w optymalnych dla rozwoju $P$. brassicae warunkach już 1 zarodnik w 10 g gleby wystarczy do zainfekowania rośliny (Rod 1996; Rennie i wsp. 2011).

Obszar występowania choroby z roku na rok się powiększa. Jest to związane $\mathrm{z}$ dużą mobilnością wytwarzanych przez $P$. brassicae zarodników przetrwalnikowych. Mogą się one rozprzestrzeniać na wiele sposobów, np. przez wody gruntowe i opadowe, na częściach roboczych i kołach maszyn rolniczych, odnóżach zwierząt czy na obuwiu pracowników. Dlatego bardzo istotne są działania mające na celu ograniczanie dalszej ekspansji patogena, do których możemy zaliczyć np. usuwanie resztek gleby oraz dezynfekcję maszyn rolniczych (Howard i wsp. 2010; Hwang i wsp. 2014).

Obecnie $P$. brassicae jest obiektem wielu prac naukowych. Prowadzone są liczne badania między innymi nad podatnością odmian, uzyskaniem odmian o podwyższonej odporności, ograniczaniem występowania kiły kapusty, czy też analizy gleby na obecność zarodników. Wymagają one wykonania wielu doświadczeń, zarówno szklarniowych, jak i laboratoryjnych. W związku z tym powstaje problem pozostawania zainfekowanego materiału roślinnego oraz zanieczyszczonej zarodnikami gleby. Są to pozostałości, na które należy zwrócić szczególną uwagę, ponieważ poddane utylizacji w nieodpowiedni sposób, mogą stanowić kolejne źródło choroby.

W ramach niniejszej pracy podjęto próbę określenia czynników wpływających na żywotność zarodników patogena $\mathrm{w}$ glebie.

Celem pracy była ocena skuteczności metod sterylizacji, wykorzystywanej w doświadczeniach szklarniowych i laboratoryjnych gleby, zanieczyszczonej zarodnikami przetrwalnikowymi $P$. brassicae.

\section{Materiały i metody / Materials and methods}

W doświadczeniu wykorzystano inokulat, który przygotowano z wyrośli na korzeniach porażonych roślin rzepaku pochodzących z obszaru południowo-zachodniej Polski. Dojrzałe narośle korzeniowe dokładnie oczyszczono i homogenizowano za pomocą blendera. Uzyskaną zawiesinę przefiltrowano przez kilkuwarstwową gazę, a następnie rozcieńczono w celu uzyskania pożądanego stężenia. Zagęszczenie zarodników P. brassicae w uzyskanym inokulacie obliczano pod mikroskopem optycznym za pomocą komory zliczeniowej według Neubauer-improved o głębokości $0,1 \mathrm{~mm}$ (Marienfeld-Superior).

W doświadczeniach, w których przeprowadzono test biologiczny wykorzystano glebę polową, pochodzącą z obszaru, na którym nie występuje kiła kapusty. Próby gleby o objętości 1 litra inokulowano zawiesiną zarodników P. brassicae o stężeniu $1 \times 10^{7}$ zarodników na $1 \mathrm{~g}$ gleby, a następnie poddawano procesom:

- spalania - za pomocą palnika gazowego,

- sterylizacji w autoklawie - w dwóch temperaturach: $121^{\circ} \mathrm{C}$ (przy ciśnieniu $205 \mathrm{kPa}$ ) oraz $136^{\circ} \mathrm{C}$ (przy ciśnieniu $320 \mathrm{kPa}$ ) w czasie: $30 \mathrm{~min}$ i $2 \times 30 \mathrm{~min}$,

- sterylizacji w aparacie Kocha - do próby gleby dodano 11 destylowanej wody i sterylizowano w czasie: $30 \mathrm{~min}$, $2 \times 30 \mathrm{~min}$ oraz $3 \times 30 \mathrm{~min}$,

- działania podwyższonej temperatury - do próby gleby dodano 11 destylowanej wody i ogrzewano w temperaturze: $100^{\circ} \mathrm{C}, 90^{\circ} \mathrm{C}, 70^{\circ} \mathrm{C}, 50^{\circ} \mathrm{C}, 40^{\circ} \mathrm{C}$ w czasie $3 \times 30 \mathrm{~min}$,

- mrożenia - w temperaturze $-80^{\circ} \mathrm{C}$ nieprzerwanie w okresie 2 dni oraz 6-krotne zamrażanie i odmrażanie,

- dezynfekcji - 3-krotne zanurzenie badanej próby gleby w roztworze dezynfektanta o stężeniu $1 \%$ lub 0,5\% i 1\% (w przypadku ACE).

Do dezynfekcji wykorzystano preparaty: ACE (s.cz. podchloryn sodu), Pest-Aut (s.cz. podchloryn sodu), Altima $500 \mathrm{SC}$ (s.cz. fluazynam $500 \mathrm{~g} / 1$ - związek z grupy pochodnych aniliny), Topsin M $500 \mathrm{SC}$ (s.cz. tiofanat metylowy $500 \mathrm{~g} / 1$ - związek z grupy benzimidazoli). Kontrolę stanowiła inokulowana gleba niepoddana żadnym zabiegom.

Próby gleb poddane sterylizacji oraz kontrolę mieszano $\mathrm{z}$ podłożem do wysiewu (Kronen) w stosunku $2: 1$. W przypadku procesu spalania, popiół mieszano z podłożem w stosunku 1 : 5. Próby umieszczano w doniczkopaletach, do których wysiano nasiona rzepaku odmiany Monolit wrażliwej na porażenie przez P. brassicae (8 powtórzeń po 5 roślin dla każdej badanej próby). Doświadczenie przeprowadzono w dwóch seriach w kabinach szklarniowych o ściśle kontrolowanych warunkach w temperaturze $20^{\circ} \mathrm{C}$ przy fotoperiodzie: 14 godzin światła/10 godzin ciemności.

Stopień porażenia roślin oceniano po 6 tygodniach w 4-stopniowej skali (Vigier i wsp. 1989), gdzie:

0 - oznacza roślinę o zdrowym systemie korzeniowym, 1 - niewielkie guzy na korzeniach bocznych (1 do 10\%), 
2 - objawy porażenia występują na 11 do 50\% systemu korzeniowego,

3 - objawy porażenia występują na 51 do $100 \%$ systemu korzeniowego.

Z uzyskanych wyników obliczono procent porażonych roślin oraz indeks porażenia (ID) według wzoru (Strelkov i wsp. 2006):

$$
\mathrm{ID}=(0 \mathrm{n} 0+1 \mathrm{n} 1+2 \mathrm{n} 2+3 \mathrm{n} 3) \times 100 / 3 \mathrm{Nt}
$$

$\mathrm{n} 0$ - n3 - liczba roślin porażonych $\mathrm{w}$ danym stopniu, $\mathrm{Nt}$ - całkowita liczba badanych roślin.

Uzyskane wyniki poddano analizie statystycznej. Porównania średnich dokonano za pomocą testu t-Studenta, wyznaczając najmniejszą istotną różnicę na poziomie istotności $5 \%$.

\section{Wyniki i dyskusja / Results and discussion}

Zanieczyszczona gleba oraz materiał roślinny, pozostałe po badaniach i doświadczeniach naukowych i hodowlanych, mogą stanowić źródło inokulum, szczególnie niebezpieczne w przypadku tak trudnego w zwalczaniu patogena, jakim jest $P$. brassicae. Aby tego uniknąć ważna jest prawidłowo przeprowadzona sterylizacja tych materiałów. Warunki i rodzaj sterylizacji powinny uwzględniać rodzaj struktur patogena, ponieważ fazy spoczynkowe są zwykle mniej wrażliwe na ciepło niż aktywnie rosnący patogen (McGovern i McSorley 1997).

Przeprowadzone doświadczenie wykazało zróżnicowany wpływ zastosowanych metod sterylizacji gleby na porażenie roślin przez $P$. brassicae (tab. 1). W wariancie doświadczenia, w którym rośliny hodowano na podłożu z dodatkiem popiołu uzyskanego ze spalenia zainokulowanej próby gleby, wartość ID oraz procent porażonych roślin wynosił $0 \%$.

Proces autoklawowania gleby $\mathrm{z}$ zarodnikami przetrwalnikowymi $P$. brassicae przeprowadzony w 2 różnych temperaturach oraz 4 wariantach czasowych, pozwolił na uzyskanie zadowalających efektów sterylizacji, jednak nie zawsze zniszczeniu uległy wszystkie zarodniki patogena. Pojedyncze rośliny z objawami kiły kapusty zaobserwowano na glebie autoklawowanej $\mathrm{w}$ temperaturze $136^{\circ} \mathrm{C}$ $(2 \times 30 \mathrm{~min})$, mimo to różnice w uzyskanych wynikach ID nie były statystycznie istotne.

Wariant doświadczenia, w którym rośliny hodowane były na glebie poddanej procesowi sterylizacji w aparacie Kocha wykazał, że nie tylko wysoka temperatura ma wpływ na niszczenie zarodników $P$. brassicae, ale również czas, w którym ta temperatura działa na patogena. Wartość ID oraz procent porażonych roślin uzyskane w tej wersji doświadczenia były odwrotnie proporcjonalne do czasu trwania zabiegu. W wariancie, w którym proces trwał najdłużej $(3 \times 30 \mathrm{~min})$ porażeniu uległo tylko 1,3\% wszystkich badanych roślin (ID 0,8\%), natomiast przy gotowaniu gleby przez 30 minut porażonych było $88,5 \%$ roślin, a ID wyniosło $76,8 \%$ (tab. 1).

$\mathrm{W}$ testach, w których rośliny rosły w glebie poddanej działaniu podwyższonych temperatur $40^{\circ} \mathrm{C}$ oraz $50^{\circ} \mathrm{C}$, uzyskany procent porażonych roślin oraz indeks porażenia był taki sam, jak w obiektach kontrolnych (100\%). Natomiast w przypadku gleb traktowanych wyższą temperaturą (powyżej $70^{\circ} \mathrm{C}$ ), zaobserwowano stopniowy spadek wartości wyżej wymienionych parametrów. W wariancie, w którym zastosowano temperaturę $100^{\circ} \mathrm{C}$ nie zaobserwowano roślin z objawami porażenia (tab. 1). Według danych przedstawionych przez Bollen (1985), temperatura letalna dla $P$. brassicae jest niższa i wynosi $50-60^{\circ} \mathrm{C}$ przy stosowaniu przez 30 minut, jednak w przeprowadzonym doświadczeniu nie udało się tego całkowicie potwierdzić.

Przeprowadzone badanie wykazało bardzo dużą trwałość zarodników przetrwalnikowych $P$. brassiceae w ekstremalnie niskich temperaturach. W obu wariantach doświadczenia, w których zastosowano głębokie mrożenie zainfekowanych prób gleb $\mathrm{w}$ temperaturze $-80^{\circ} \mathrm{C}$ zaobserwowano, podobnie jak w kontroli, 100\% porażenie roślin, jak również wartość ID równą 100\% (tab. 1).

Wśród środków chemicznych zastosowanych w doświadczeniu, największą skutecznością sterylizacji gleby charakteryzował się środek Altima 500 SC, zawierający substancję czynną - fluazynam. Środek ten jest obecnie zarejestrowany w Polsce do stosowania w ochronie przed kiłą kapusty wyłącznie w uprawach kapusty białej i pekińskiej. Producent zaleca stosowanie $0,05 \%$ roztworu preparatu w przypadku podlewania roślin oraz dawki 2 1/ha do polowej sterylizacji gleby. W doświadczeniu zastosowano $1 \%$ roztwór tego fungicydu, co pozwoliło na obniżenie wartości indeksu porażenia roślin do $0,3 \%$ przy $0,77 \%$ porażonych roślin. Dużą skuteczność Altima 500 SC w zwalczaniu P. brassicae w warunkach polowych potwierdzają również liczne badania, w tym Robaka (2001), Kurowskiego i Bruderka (2004) oraz Kurowskiego i wsp. (2008, 2009).

Drugi badany fungicyd Topsin M 500 SC, zastosowany w doświadczeniu w stężeniu 1\%, wykazał bardzo niską skuteczność. Indeks porażenia oraz procent porażonych roślin przekraczały 96\% i były zbliżone do wyników uzyskanych w kontroli. Topsin M 500 SC jest zarejestrowany do ograniczania rozwoju kiły kapusty w rzepaku ozimym i jego pozytywne działanie w uprawach polowych oraz szklarniowych potwierdzają badania Jajor i wsp. (2009) oraz Kurowskiego (2015). Brak skuteczności w dezynfekcji gleby w przeprowadzonym doświadczeniu może być spowodowany zastosowaniem bardzo wysokiego stężenia inokulum patogena, które w naturalnych warunkach polowych występuje rzadko lub na ograniczonym obszarze pola. 
Tabela 1. Indeks porażenia (ID) oraz procent porażonych roślin w poszczególnych wariantach doświadczenia [\%] Table 1. Index of disease (ID) and the percentage of infected plants in each experimental treatment [\%]

\begin{tabular}{|c|c|c|c|c|c|}
\hline $\begin{array}{l}\text { Proces / środek chemiczny } \\
\text { Process / chemical agent }\end{array}$ & $\begin{array}{l}\text { Temperatura } \\
\text { (ciśnienie) } \\
\text { Temperature } \\
\text { (pressure) }\end{array}$ & $\begin{array}{l}\text { Czas } \\
\text { Time }\end{array}$ & $\begin{array}{c}\text { Stężenie } \\
\text { Concentration }\end{array}$ & $\begin{array}{c}\text { Procent } \\
\text { porażonych roślin } \\
\text { Percentage } \\
\text { of infected plants } \\
{[\%]}\end{array}$ & $\begin{array}{l}\text { ID } \\
{[\%]}\end{array}$ \\
\hline $\begin{array}{l}\text { Spalanie } \\
\text { Combustion }\end{array}$ & - & - & - & 0 & 0 \\
\hline $\begin{array}{l}\text { Autoklawowanie } \\
\text { Autoclaving }\end{array}$ & $\begin{array}{c}121^{\circ} \mathrm{C} \\
(205 \mathrm{kPa}) \\
\\
136^{\circ} \mathrm{C} \\
(320 \mathrm{kPa})\end{array}$ & $\begin{array}{l}30 \mathrm{~min} \\
2 \times 30 \mathrm{~min} \\
30 \mathrm{~min} \\
2 \times 30 \mathrm{~min}\end{array}$ & $\begin{array}{l}- \\
- \\
- \\
-\end{array}$ & $\begin{array}{c}0 \\
0 \\
0 \\
1,3\end{array}$ & $\begin{array}{c}0 \\
0 \\
0 \\
0,6\end{array}$ \\
\hline $\begin{array}{l}\text { Sterylizacja w aparacie Kocha } \\
\text { Sterilization in the Koch } \\
\text { apparatus }\end{array}$ & $\begin{array}{l}>100^{\circ} \mathrm{C} \\
>100^{\circ} \mathrm{C} \\
>100^{\circ} \mathrm{C}\end{array}$ & $\begin{array}{l}30 \mathrm{~min} \\
2 \times 30 \mathrm{~min} \\
3 \times 30 \mathrm{~min}\end{array}$ & $\begin{array}{l}- \\
- \\
-\end{array}$ & $\begin{array}{l}88,5 \\
12,7 \\
1,3\end{array}$ & $\begin{array}{l}76,8 \\
7,14 \\
0,8\end{array}$ \\
\hline $\begin{array}{l}\text { Działanie podwyższonej } \\
\text { temperatury } \\
\text { Operation of increased } \\
\text { temperature }\end{array}$ & $\begin{array}{l}100^{\circ} \mathrm{C} \\
90^{\circ} \mathrm{C} \\
70^{\circ} \mathrm{C} \\
50^{\circ} \mathrm{C} \\
40^{\circ} \mathrm{C}\end{array}$ & $\begin{array}{l}3 \times 30 \mathrm{~min} \\
3 \times 30 \mathrm{~min} \\
3 \times 30 \mathrm{~min} \\
3 \times 30 \mathrm{~min} \\
3 \times 30 \mathrm{~min}\end{array}$ & $\begin{array}{l}- \\
- \\
- \\
- \\
-\end{array}$ & $\begin{array}{c}0 \\
48,8 \\
53,8 \\
100 \\
100\end{array}$ & $\begin{array}{c}0 \\
38,2 \\
32,5 \\
100 \\
100\end{array}$ \\
\hline $\begin{array}{l}\text { Zamrażanie } \\
\text { Freezing }\end{array}$ & $\begin{array}{l}-80^{\circ} \mathrm{C} \\
-80^{\circ} \mathrm{C}\end{array}$ & $\begin{array}{c}2 \text { dni } \\
2 \text { days } \\
\text { 6-krotne odmrażanie } \\
\text { i zamrażanie } \\
\text { 6-times defrosting } \\
\text { and freezing }\end{array}$ & - & 100 & 100 \\
\hline $\mathrm{ACE}$ & $\begin{array}{l}- \\
-\end{array}$ & $\begin{array}{l}- \\
-\end{array}$ & $\begin{array}{l}0,5 \% \\
1 \%\end{array}$ & $\begin{array}{l}92,7 \\
\text { toksyczny d } \\
\text { toxic to }\end{array}$ & 91,3 \\
\hline Pest-Aut & - & - & $1 \%$ & 99,1 & 97,2 \\
\hline Altima $500 \mathrm{SC}$ & - & - & $1 \%$ & 0,77 & 0,3 \\
\hline Topsin M $500 \mathrm{SC}$ & - & - & $1 \%$ & 97,7 & 96,2 \\
\hline Kontrola - Control & - & - & - & 100 & 100 \\
\hline \multicolumn{5}{|l|}{$\operatorname{NIR}(0,05)-\operatorname{LSD}(0.05)$} & 2,984 \\
\hline
\end{tabular}

Badania skuteczności chemicznych środków dezynfekcyjnych przeciwko $P$. brassicae prowadzone przez Howard i wsp. (2014) pod kątem oczyszczania maszyn i pojazdów rolniczych wskazują, że najskuteczniejsze są preparaty zawierające: podchloryn sodu, nadtlenek wodoru, kwas octowy i peroksymonosiarczan potasu. Jednak zastosowane w przeprowadzonym doświadczeniu preparaty zawierające podchloryn sodu były nieskuteczne w dezynfekcji gleby.
Rośliny hodowane w glebie traktowanej $1 \%$ roztworem preparatu Pest-Aut, jak również 0,5\% roztworem ACE uzyskały wartości ID oraz procent porażonych roślin przekraczające 90\%. Ponadto zastosowanie ACE w stężeniu 1\% było toksyczne dla roślin, co uniemożliwiło uzyskanie wyniku w zastosowanym teście biologicznym.

Przeprowadzona analiza statystyczna potwierdziła, że najwyższą skutecznością wśród analizowanych metod 
sterylizacji charakteryzowały się procesy: spalania, autoklawowania, działania wysokiej temperatury (minimum $100^{\circ} \mathrm{C}$ ) w czasie $3 \times 30$ minut oraz zastosowanie fungicydu Altima $500 \mathrm{SC}$

Spalanie pozwala na całkowite zniszczenie zawartej w glebie materii organicznej, a zatem można mieć pewność, że prawidłowo wykonane, zniszczy wszystkie zarodniki przetrwalnikowe patogena. Niestety w związku z brakiem możliwości przeprowadzenia tej metody sterylizacji w warunkach laboratoryjnych, jest ona trudna w realizacji. Stosowane powszechnie w laboratoriach autoklawowanie lub sterylizacja w aparacie Kocha zanieczyszczonego patogenami materiału, w przypadku P. brassicae miało wysoką skuteczność, jednak nie zawsze pozwalało na całkowite zniszczenie wszystkich zarodników. Niewątpliwą zaletą tych metod jest niski koszt, dostępność aparatury oraz łatwość wykonania. $\mathrm{Na}$ uwagę zasługuje również fungicyd Altima 500 SC. Metoda sterylizacji gleby roztworem tego preparatu może stanowić dobrą alternatywę w przypadku konieczności szybkiej dezynfekcji małej partii materiału, jednak stosowanie go na większą skalę może być pracochłonne i kosztowne.

W związku z różnymi metodami prowadzenia doświadczeń, rodzajem dostępnego sprzętu i poziomem zanie- czyszczenia utylizowanej gleby, skuteczność opisanych metod może być niższa. Dlatego zaleca się wykonanie testu biologicznego, w celu potwierdzenia skuteczności wybranej metody sterylizacji gleby w konkretnych warunkach danego laboratorium.

\section{Wnioski / Conclusions}

1. W związku z możliwością całkowitego zniszczenia wszystkich zarodników przetrwalnikowych P. brassicae, najskuteczniejszą metodą sterylizacji zanieczyszczonej nimi gleby jest spalanie.

2. Sterylizacja za pomocą autoklawowania, działania wysokiej temperatury oraz dezynfekcja fungicydem Altima 500 SC mogą być przydatne do sterylizacji gleby ze względu na wysoką skuteczność tych metod.

3. Zarodniki przetrwalnikowe P. brassicae charakteryzują się dużą trwałością w bardzo niskich temperaturach.

4. Stwierdzono, że na obniżenie żywotności zarodników przetrwalnikowych $P$. brassicae w glebie wpływa wysoka temperatura (powyżej $70^{\circ} \mathrm{C}$ ), jak również czas jej działania na patogena.

\section{Literatura / References}

Bollen G.J. 1985. Lethal temperatures of soil fungi. W: Ecology and Management of Soil-borne Pathogens (C.A. Parker, A.D. Rovira, K.J. Moore, P.T.W. Wong, J.F. Kollmorgen, red.). APS Press, St. Paul, Minnesota: 191-193.

Howard R.J., Burke D.A., Strelkov S.E., Rennie D.C., Pugh C.A., Lisowski S.L.I., Harding M.W., Daniels G.C. 2014. Evaluation of methods for cleaning and disinfesting equipment contaminated with clubroot. Abstracts/Résumés - Annual Meeting 2013. Canadian Journal of Plant Pathology 36 (2): 266.

Howard R.J., Strelkov S.E., Harding M.W. 2010. Clubroot of cruciferous crops - new perspectives on an old disease. Canadian Journal of Plant Pathology 32 (1): 43-57. DOI: 10.1080/07060661003621761.

Hwang S.-F., Howard R.J., Strelkov S.E., Gossen B.D., Peng G. 2014. Management of clubroot (Plasmodiophora brassicae) on canola (Brassica napus) in western Canada. Canadian Journal of Plant Pathology 36 (1): 49-65. DOI: 10.1080/07060661.2013.863806.

Jajor E., Korbas M., Budka A. 2009. Ograniczanie kiły kapusty (Plasmodiophora brassicae) w rzepaku ozimym przy użyciu tiofanatu metylu. [Reduction of clubroot (Plasmodiophora brassicae) on winter oilseed rape using methyl tiophanate]. Progress in Plant Protection/Postępy w Ochronie Roślin 49 (3): 1268-1272.

Konieczny W. 2012. Kiła opanowała 250 tys. hektarów. Farmer 5: 38-42.

Korbas M., Jajor E. 2013. Kiła kapusty - narastający problem w uprawie rzepaku. Materiały informacyjne. Instytut Ochrony Roślin Państwowy Instytut Badawczy, Poznań, Syngenta, Warszawa, 15 ss.

Korbas M., Jajor E., Budka A. 2009. Clubroot (Plasmodiophora brassicae) - a threat for oilseed rape. [Kiła kapusty (Plasmodiophora brassicae) zagrożeniem dla rzepaku]. Journal of Plant Protection Research 49 (4): 446-451. DOI: 10.2478/v10045-009-0071-8.

Kurowski T.P. 2015. Kiła kapusty zagrożeniem rzepaku w Polsce. Poradnik Gospodarski 9: 12-13.

Kurowski T.P., Bruderek A. 2004. Próba ochrony rzepaku ozimego przed kiłą kapusty (Plasmodiophora brassicae Wor.) przy użyciu fungicydu Altima 500 SC. [Trial of winter oilseed rape protection against clubroot (Plasmodiophora brassicae Wor.) with Altima 500 SC fungicide]. Progress in Plant Protection/Postępy w Ochronie Roślin 44 (2): 893-895.

Kurowski T.P., Majchrzak B., Jaźwińska E., Wysocka U. 2008. Skuteczność fungicydu zawierającego fluazynam w ochronie rzepaku ozimego przed kiłą kapusty (Plasmodiophora brassicae Woronin). [Effectiveness of a fungicide containing fluazinam for the protection of winter rape against club root (Plasmodiophora brassicae Woronin)]. Progress in Plant Protection/Postępy w Ochronie Roślin 48 (1): 212-215.

Kurowski T.P., Majchrzak B., Kowalska E. 2009. The effectiveness of the biological control of clubroot (Plasmodiophora brassicae) in brassicaceae plants. [Skuteczność preparatów biologicznych w ochronie roślin kapustowatych przed kiłą kapusty (Plasmodiophora brassicae)]. Phytopathologia 52: 5-12.

McGovern R.J., McSorley R. 1997. Physical methods of soil sterilization for disease management including soil solarisation. Chapter 12. s. 283-312. W: Environmentally Safe Approaches to Crop Disease Control (J.E. Rechcigl, N.A. Rechcigl, red.). CRC Press, 399 ss. ISBN 978-131-589-27-26. 
Rennie D.C., Manolii V.P., Cao T., Hwang S.F., Howard R.J., Strelkov S.E. 2011. Direct evidence of surface infestation of seeds and tubers by Plasmodiophora brassicae and quantification of spore load. Plant Pathology 60 (5): 811-819. DOI: 10.1111/j.1365-3059 .2011.02449.x.

Rimmer S.R., Shattuck V.I., Buchwaldt L. 2007. Compendium of Brassica Diseases. The APS, St. Paul, MN, 117 ss.

Robak J. 2001. Altima 500 SC - nowa możliwość w integrowanej ochronie warzyw przed kiłą kapustnych. [Altima 500 SC - new possibility in integrated protection of vegetables against clubroot]. Owoce, Warzywa, Kwiaty 9: 38.

Rod J. 1996. Reports - Agent of clubroot of crucifer. Central Institute for Supervising and Testing in Agriculture (ÚKZÚZ), Brno, UKZUZ 37 (Special Issue): $1-45$.

Strelkov S.E., Tewari J.P., Smith-Degenhardt E. 2006. Characterization of Plasmodiophora brassicae populations from Alberta, Canada. Canadian Journal of Plant Pathology 28 (3): 467-474. DOI: 10.1080/07060660609507321.

Vigier B., Chiang M.S., Hume D.J. 1989. Source of resistance to clubroot (Plasmodiophora brassicae Wor.) in triazine-resistant spring canola (rapeseed). Canadian Plant Disease Survey 69 (2): 113-115.

Wallenhammar A.-C. 1996. Prevalence of Plasmodiophora brassicae in a spring oilseed rape growing area in central Sweden and factors influencing soil infestation levels. Plant Pathology 45 (4): 710-719. DOI: 10.1046/j.1365-3059.1996.d01-173.x. 